\title{
17. ORGANIC GEOCHEMISTRY IN THE MESOZOIC AND CENOZOIC FORMATIONS OF SITE 534, LEG 76, BLAKE-BAHAMA BASIN, AND COMPARISON WITH SITE 391, LEG $44^{1}$
}

\author{
J. P. Herbin, G. Deroo, and J. Roucaché, Géologie et Géochimie, Institut Français du Pétrole, \\ Rueil-Malmaison, France
}

\begin{abstract}
The geochemical studies of Sites 534 and 391 and their comparison allow us to improve the chemical characterization of different geological formations dating from the early Callovian to the Maestrichtian along the continental margin of eastern North America.

Three of the formations are favorable for the preservation of organic matter: (1) the unnamed formation (middle Callovian to Oxfordian), (2) the Blake-Bahama Formation (Berriasian to Barremian), and (3) the Hatteras Formation (Aptian to Cenomanian). The organic matter is mainly detrital, except for a few organic-rich layers where a contribution of aquatic material occurs. In these organic-rich layers, the petroleum potential is medium to good. Maturation has not quite reached the beginning of the oil window even for the deepest organic material.
\end{abstract}

\section{INTRODUCTION}

Hole $391 \mathrm{C}$ of Leg 44 and nearby Hole 534A of Leg 76 (Fig. 1), penetrate the same geological formations.

We studied 33 samples of the latter. They came from the following formations (Fig. 2): Great Abaco Member, Bermuda Rise Formation, Plantagenet Formation, Hatteras Formation, Blake-Bahama Formation, Cat Gap Formation, and a new unit-the unnamed formationbeneath the Cat Gap Formation. This new unit makes it possible to study the sediments deposited during the proto-oceanic stage of seafloor spreading in the Atlantic.

Since the publication of data in the Leg 44 Initial Reports (Deroo et al., 1978), a large number of additional analyses of Hole 391C samples have been made in our laboratory. In order to define the geochemical characteristics of the different formations, the new data available for 92 samples from Hole 391C will also be considered here.

All samples were studied with a LECO apparatus in order to investigate the amount of total organic carbon, and with a Rock Eval apparatus (Espitalié et al., 1977) to determine the petroleum generating potential, the nature of the organic material, and its stage of maturation. Furthermore, in some samples rich in organic carbon we studied the extractable compounds.

The first part of this report is devoted to the results of the carbon analyses and the nature of the organic matter, the second part to the petroleum potential and maturation of the organic matter, and the third part deals with the composition of the chloroform extracts. In each part the geological order is followed for both the formations (from older to younger) and the lithological subunits (from bottom to top) within each formation.

\footnotetext{
${ }^{1}$ Sheridan, R. E., Gradstein, F. M., et al., Init. Repts. DSDP, 76: Washington (U.S. Govt. Printing Office).
}

\section{MINERAL CARBON, ORGANIC CARBON, AND TYPE OF ORGANIC MATTER IN THE DIFFERENT FORMATIONS OF HOLES 391C AND 534A}

Both pyrolyses and elemental analyses of kerogens enabled us to characterize the samples in relation to the different reference types of organic matter described in Tissot et al. (1974) and Espitalié et al. (1977). The samples can be assigned either to aquatic organic matter (Type II), to continental organic matter (Type III), or to residual organic matter (when they have a very low hydrogen index [H.I.] or H/C ratio) (Tissot et al., 1979). Residual organic matter has undergone strong alteration or oxidation before its deposition. Frequently, samples are located between the different reference paths and can be assigned either to Type II + residual, or to Type II + III, or to Type III + residual (see Fig. 3). Moreover, when the H.I. is very low $(<50)$ and the O.I. (oxygen index) very high $(>200)$, the organic matter is called undetermined; usually the related samples have a very low organic carbon content $(0.2 \%$ and less). The origin of such an undetermined organic matter could be aquatic or continental.

\section{Unnamed Formation}

This Callovian to Oxfordian unit corresponds to Unit 1 (unsampled facies) of Leg 44 (Sheridan et al., 1978). We studied seven samples of this formation from Hole 534A. Three subunits were distinguished, and they are designated from bottom to top as $7 \mathrm{c}, 7 \mathrm{~b}$, and $7 \mathrm{a}$ (Fig. 2) $)^{2}$.

Subunit $7 c$ (Samples 534A-127, CC $[10 \mathrm{~cm}]$ to $534 \mathrm{~A}$ $125-4,14 \mathrm{~cm}$ ) is dated Callovian and is composed of greenish black to olive black nannofossil claystone to carbonaceous claystone. The basal contact is located at

\footnotetext{
${ }^{2}$ Editor's note: See Site 534 report for a new subdivision of Unit 7.
} 


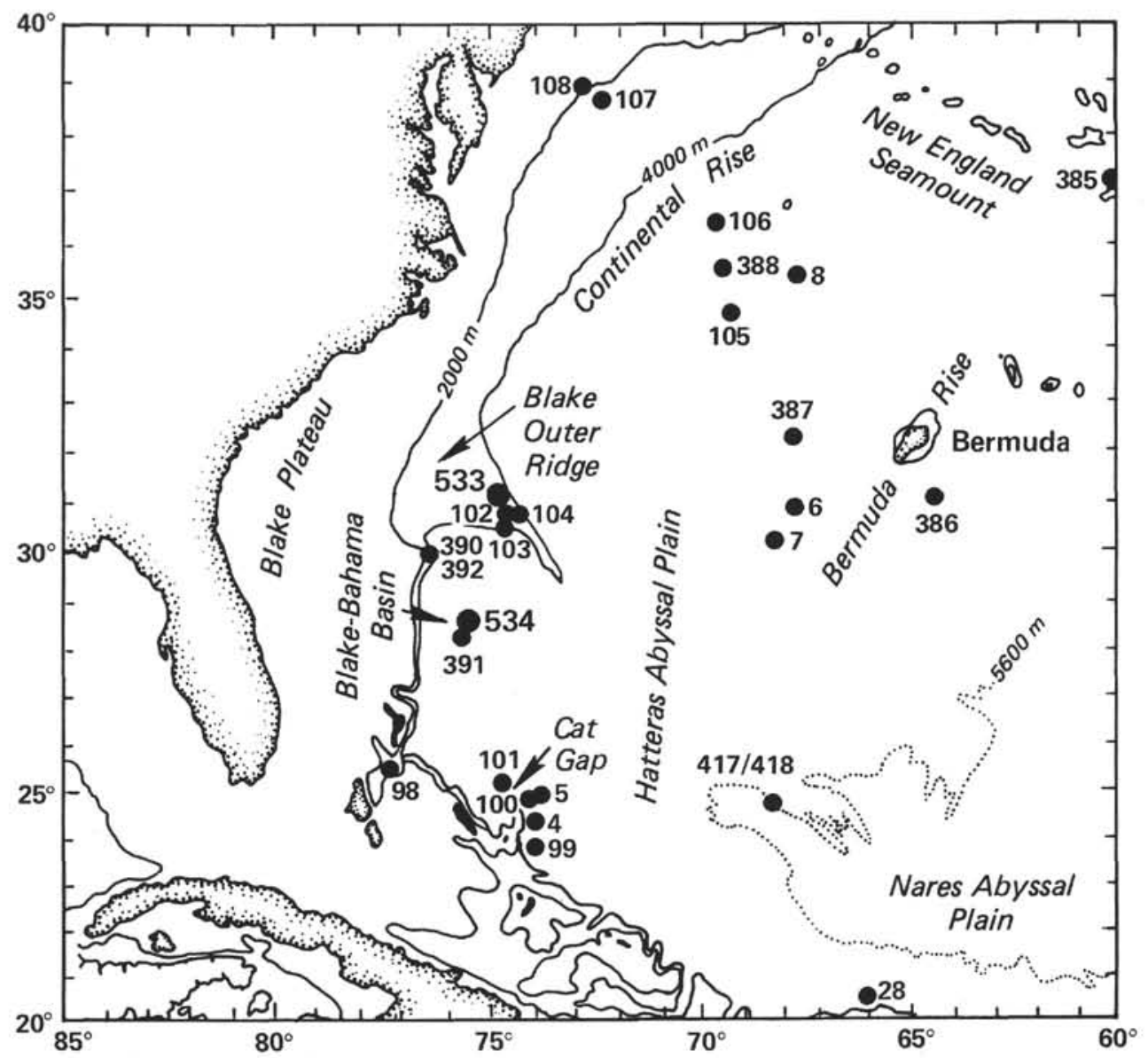

Figure 1. Location of Site 534.

Sample 534A-127,CC, $(10 \mathrm{~cm})$. The two samples studied (Table 1) show a low carbonate content $(20-22 \%$ $\mathrm{CaCO}_{3}{ }^{3}$ ). The olive black claystone of Sample 534A-126$6,76 \mathrm{~cm}$ is the richer in organic carbon $(3.1 \%)$, and the organic matter has a mixed origin: detrital and mainly aquatic (H.I. = 221, Fig. 3). The other sample studied is lean in organic carbon $(0.4 \%)$ and contains an organic matter of mainly a terrestrial origin (H.I. $=58$ ).

Subunit $7 b$ (Samples 534A-125-4, $14 \mathrm{~cm}$ to 534A-117$1,26 \mathrm{~cm}$ ) is dated Callovian to Oxfordian and is composed of dark greenish gray claystones containing silty layers of concentrated radiolarians (Cores 125-120) and of olive gray limestone interbedded with dark (blackish red, olive gray, or greenish black) variegated claystone (Cores 119-117). From Cores 125 to 120 , four samples were studied (Table 1$)$. The silty gray marls contain between 70 and $84 \% \mathrm{CaCO}_{3}$ and they are low in organic carbon $(0.4-0.5 \%)$. The organic matter is mainly terrestrial. In the gray or dark clays the percentages of $\mathrm{CaCO}_{3}$ fluctuate between 21 and $26 \%$, and the organic carbon between 0.9 and $1.8 \%$. In the richer sample (534A-125$2,100 \mathrm{~cm}$ ) the organic matter has a mixed origin (i.e., it is predominantly detrital organic matter with some marine material-H.I. = 161, cf., Fig. 3). From Cores 119

\footnotetext{
${ }^{3}$ The analyses provided the mineral carbon; then we calculated an equivalent $\mathrm{CaCO}_{3}$ as if لll the carbonates were calcium carbonate.
}

to 117 , the sediments are mainly composed of turbidites (as in Subunit $7 \mathrm{a}$ ), with poor recovery $(10 \%)$; no sampling was made.

Subunit $7 a$ Sample 534A-117-1, $26 \mathrm{~cm}$ to Core 534A111 ) is dated Oxfordian and is composed of dark variegated claystones, occasionally interbedded with micritic limestones. In these cores the recovery was very poor $(10 \%)$, perhaps because of the turbiditic texture of the sediments. Only one sample was collected (534A-112-1, $106 \mathrm{~cm}$, Table 1). It is rather calcareous (around 58\% $\left.\mathrm{CaCO}_{3}\right)$ and has a low organic carbon content $(0.2 \%)$, so that the organic matter is undetermined (Fig. 3).

The sediments of the "unnamed formation" are the oldest recovered in the present oceans. Therefore it is difficult to judge if these black claystones reflect a widespread low oxygen event or a very local feature (Site 534 report, this volume). However, the same type of lithology is found in the late Lias to Oxfordian deposits of "Terres Noires" from the basins of southeastern France.

\section{Cat Gap Formation}

This formation, recognized at Site 391 (Unit 2, Sheridan et al., 1978), was defined by Jansa et al. (1979) at Site 105. In Hole 534A two subunits were distinguished; these are discussed from bottom to top next.

Subunit $6 b$ (Cores 534A-110 to 104) is dated Oxfordian to Kimmeridgian and is composed of interbedded 


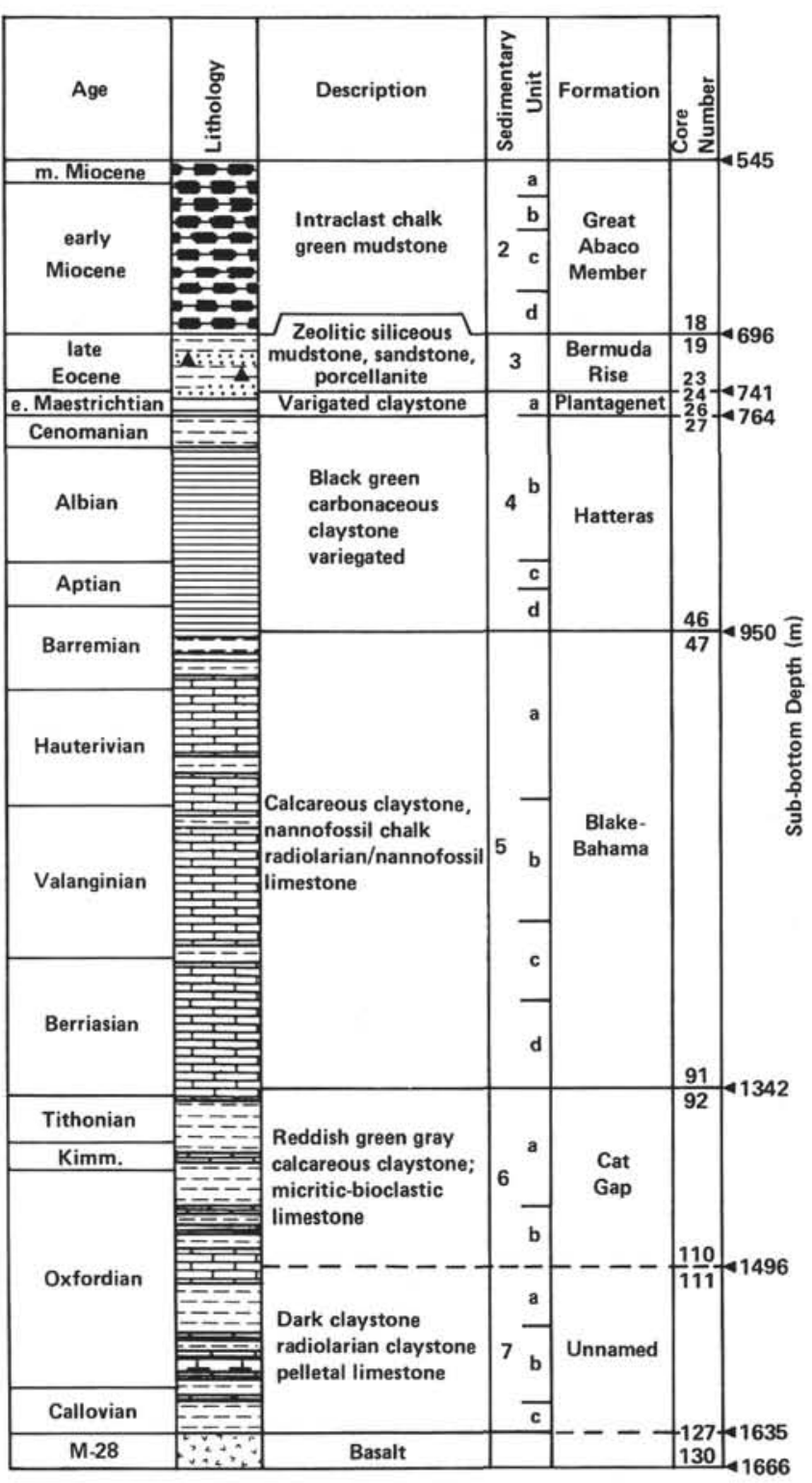

Figure 2. Schematic log of Hole 534A.

light gray limestones and dark greenish gray claystone. Carbonates represent the turbiditic component and the claystones the pelagic background. One sample was studied (534A-107-2, $6 \mathrm{~cm}$ ). It contains $25 \%$ carbonate as $\mathrm{CaCO}_{3}$ and $0.6 \%$ organic carbon of undetermined origin. No signal for hydrocarbons was obtained during pyrolysis $($ H.I. $=0)$, reflecting severe conditions of alteration and oxidation.

Subunit $6 a$ (Core 534A-103 to Sample 534A-92-2, 40 $\mathrm{cm}$ ) is dated Kimmeridgian to Tithonian and is composed of grayish red calcareous claystone. Greenish gray coloration occurs in local mottles, probably caused by local reduction of iron oxide. Five samples were studied in this subunit (Table 1). They contain diverse amounts of carbonate $\left(17-68 \% \mathrm{CaCO}_{3}\right)$, and are very low in organic carbon $(0.1-0.2 \%)$ of undetermined origin, reflecting the same deposition conditions as in Subunit $6 \mathrm{~b}$.
The Cat Gap Formation was also studied between Cores 45 and 52 of Hole 391C (Table 2). The lithofacies consists of variegated argillaceous calcilutite (Subunit 5a) and very dark red calcareous Tithonian claystone (Subunit 5b). As at Hole 534A, the samples are diversely calcareous $\left(12-47 \% \mathrm{CaCO}_{3}\right)$; they are also somewhat richer in organic carbon $(0.8-0.9 \%)$. The organic matter is generally undetermined, with a very low H.I. $(<33)$ and a high O.I. (Fig. 3). As at Hole 534A, oxidation of organic matter must be very important.

\section{Blake-Bahama Formation}

The type locality of this formation was defined by Jansa et al. (1979) at Site 391. In Hole 534A four subunits subdivide the Blake-Bahama Formation between Core 47 and Sample 534A-92-2, $40 \mathrm{~cm}$ (Fig. 2). These subunits are discussed from bottom to top next.

Subunit $5 d$ (Cores 534A-92 to 84), dated Berriasian, is composed of greenish gray marly nannofossil chalk or limestone interbedded with dark greenish gray claystone. One sample (534A-91-3, $52 \mathrm{~cm}$ ) was studied after being divided into two parts: a marl with $52 \% \mathrm{CaCO}_{3}$ and a limestone with $64 \%$. The organic carbon values are so low $(0.2-0.3 \%)$ that no hydrocarbon response was observed during pyrolysis (H.I. $=0$, Table 1 ). Extensive alteration and oxidation can be inferred.

Subunit 5c (Cores 534A-83 to 76), dated Berriasian to early Valanginian, is composed of rhythmic intercalations of fine laminated radiolarian marly chalks (light gray to light olive gray) and graded claystones (greenish black). No samples were analyzed.

Subunit $5 b$ (Cores 534A-75 to 65), dated late Valanginian, is similar to Subunit $5 \mathrm{c}$, but is characterized by less heterogenous intercalations. Two sets of two samples were studied in this unit (534A-72-6, $16 \mathrm{~cm}$ and 534A-71-4 $42 \mathrm{~cm}$, see Table 1) because of the heterogeneity of the lithology. The darker samples are the leaner in carbonate content $\left(17\right.$ and $\left.34 \% \mathrm{CaCO}_{3}\right)$, whereas the lighter samples are richer (60 and $64 \%)$. The organic carbon content fluctuates between 1.5 and $2.8 \%$, regardless of color and carbonate content. The pyrolysis indices are also independent of color and carbonate. They imply that the organic matter is of detrital origin, with some contribution of aquatic material in the more carbonaceous sample (534A-72-6, $16 \mathrm{~cm}$, Fig. 3).

Subunit $5 a$ (Cores 534A-64 to 47), which is dated Hauterivian to Barremian, is composed of calcareous claystone and marly nannofossil chalks, the greenish gray calcareous claystone being redeposited pelagic sediments. The samples studied are marly $\left(30-57 \% \mathrm{CaCO}_{3}\right)$ and rich in organic carbon (1.2-3.1\%, Table 1). But pyrolysis shows a predominantly detrital organic matter, except for two samples (534A-52-2, $51 \mathrm{~cm}$ and 534A$49-1,10 \mathrm{~cm}$ ) in which there may be some contribution of aquatic organic matter (H.I. $=263$ and 187, Fig. 3).

Recent studies in the Cretaceous of the North Atlantic (C. Müller et al., personal communication, 1982; de Graciansky et al., 1982) show that there is a discontinuity-the E1 Event-at the top of the Blake-Bahama Formation, before the deposition of the Hatteras Forma- 
Table 1. Carbonate, organic carbon, and pyrolysis data for Hole 534A samples.

\begin{tabular}{|c|c|c|c|c|c|c|c|c|c|c|}
\hline $\begin{array}{c}\text { Sample } \\
\text { (core-section, } \\
\text { interval } \\
\text { in } \mathrm{cm} \text { ) }\end{array}$ & $\begin{array}{l}\text { Depth } \\
\text { below } \\
\text { seafloor } \\
\text { (m) }\end{array}$ & $\begin{array}{c}\text { Geologica } \\
\text { formation } \\
\text { (Fm.) and } \\
\text { lithologica } \\
\text { units }\end{array}$ & & $\begin{array}{l}\text { Mineral } \\
\text { carbon } \\
\text { (wt. \%) }\end{array}$ & $\begin{array}{l}\mathrm{CaCO}_{3} \\
\text { equivalent } \\
\text { (wt.\%) }\end{array}$ & $\begin{array}{l}\text { Organic } \\
\text { carbon } \\
\text { (wt. } \% \text { ) }\end{array}$ & $\begin{array}{l}\text { Hydrogen } \\
\text { index (mg hydro- } \\
\text { carbons versus g } \\
\text { organic carbon) }\end{array}$ & $\begin{array}{c}\text { Oxygen } \\
\text { index (mg } \\
\mathrm{CO}_{2} \text { versus } \mathrm{g} \\
\text { organic carbon) }\end{array}$ & $\begin{array}{c}\text { Petroleum } \\
\text { potential } \\
\text { (kg hydrocarbons } \\
\text { versus } \mathrm{T} \text { of rock) }\end{array}$ & $\begin{array}{l}\text { Pyrolysis } \\
\text { tempera- } \\
\text { ture } \\
\left({ }^{\circ} \mathrm{C}\right)\end{array}$ \\
\hline $16-2,72$ & 671.72 & \multirow{2}{*}{\multicolumn{2}{|c|}{$\begin{array}{c}\text { Great Abaco } \\
\text { Member }\end{array}$}} & 9.2 & 77 & 0.3 & 103 & 553 & 0.33 & 409 \\
\hline $18-2,51$ & 689.51 & & & 10.1 & 84 & 0.3 & 157 & 475 & 0.44 & 422 \\
\hline $19-3,76$ & 700.66 & \multirow{2}{*}{\multicolumn{2}{|c|}{$\begin{array}{l}\text { Bermuda } \\
\text { Rise Fm. }\end{array}$}} & 1.3 & 11 & 0.1 & 18 & 313 & 0.01 & 355 \\
\hline $20-3,63$ & 709.13 & & & 11.5 & 96 & 0.1 & 0 & 488 & 0.00 & \\
\hline $24-1,30$ & 742.30 & \multirow{2}{*}{\multicolumn{2}{|c|}{$\begin{array}{l}\text { Plantagenet } \\
\text { Fm. }\end{array}$}} & 0.6 & 5 & 0.1 & 0 & 300 & 0.00 & \\
\hline $25-1,130$ & 751.80 & & & 0.9 & 7 & 0.3 & 21 & 214 & 0.08 & 332 \\
\hline $27-2,82$ & 766.82 & \multirow{3}{*}{$\begin{array}{c}\text { Hatteras } \\
\text { Fm. }\end{array}$} & \multirow{3}{*}{$4 a$} & 1.1 & 9 & 0.9 & 21 & 106 & 0.21 & 376 \\
\hline $34-2,70$ & 833.20 & & & 1.2 & 10 & 0.9 & 15 & 91 & 0.12 & 390 \\
\hline $36-3,120$ & 854.20 & & & 1.4 & 11 & 2.6 & 115 & 62 & 2.98 & 428 \\
\hline $49-1,10$ & 963.60 & \multirow{5}{*}{\multicolumn{2}{|c|}{$5 a$}} & 4.3 & 35 & 3.1 & 187 & 83 & 5.81 & 425 \\
\hline $50-1,59$ & 973.09 & & & 3.8 & 32 & 1.5 & 47 & 120 & 0.73 & 412 \\
\hline $52-2,59$ & 992.51 & & & 6.9 & 57 & 2.8 & 263 & 97 & 7.44 & 425 \\
\hline $55-2,57$ & 1019.57 & & & 4.6 & 38 & 1.4 & 44 & 131 & 0.60 & 421 \\
\hline $56-2,47$ & 1030.47 & & & 3.6 & 30 & 1.2 & 19 & 150 & 0.22 & 410 \\
\hline $71-4,42$ & 1161.92 & Bahama & \multirow{4}{*}{$5 b$} & 4.1 & 34 & 1.5 & 49 & 95 & 0.71 & 425 \\
\hline $71-4,42$ & 1161.92 & Fm. & & 7.3 & 60 & 2.1 & 30 & 65 & 0.63 & 418 \\
\hline $72-6,16$ & 1173.66 & & & 2.0 & 17 & 2.0 & 25 & 71 & 0.50 & 423 \\
\hline $72-6,15$ & 1173.66 & & & 7.7 & 64 & 2.8 & 145 & 82 & 4.00 & 429 \\
\hline $91-3,52$ & 1334.52 & & \multirow{2}{*}{$5 \mathrm{~d}$} & 6.3 & 52 & 0.3 & 0 & 300 & 0.00 & \\
\hline $91-3,52$ & 1334.52 & & & 9.4 & 78 & 0.2 & 0 & 494 & 0.00 & \\
\hline $92-6,53$ & 1348.03 & \multirow{6}{*}{$\begin{array}{c}\text { Cat Gap } \\
\text { Fm. }\end{array}$} & \multirow{5}{*}{$6 a$} & 7.3 & 61 & 0.1 & 0 & 529 & 0.00 & \multirow{5}{*}{410} \\
\hline $92-6,52$ & 1348.03 & & & 8.1 & 68 & 0.1 & 0 & 562 & 0.00 & \\
\hline $93-2,97$ & 1351.47 & & & 6.0 & 50 & 0.2 & 16 & 345 & 0.03 & \\
\hline $94-3,83$ & 1357.33 & & & 2.1 & 17 & 0.2 & 0 & 356 & 0.00 & \\
\hline $96-1,118$ & 1379.68 & & & 3.7 & 31 & 0.2 & 0 & 365 & 0.02 & \\
\hline $107-2,5$ & 1465.56 & & $6 \mathrm{~b}$ & 3.1 & 25 & 0.6 & 0 & 114 & 0.00 & \\
\hline $112-1,106$ & 1505.56 & \multirow{7}{*}{$\begin{array}{l}\text { Unnamed } \\
\text { fm. }\end{array}$} & $7 \mathrm{a}$ & 6.9 & 58 & 0.2 & 0 & 231 & 0.00 & \\
\hline $122-1,35$ & 1590.35 & & \multirow{4}{*}{$7 \mathrm{~b}$} & 8.5 & 70 & 0.5 & 70 & 115 & 0.32 & 429 \\
\hline $123-3,20$ & 1597.20 & & & 3.1 & 26 & 0.9 & 102 & 81 & 0.88 & 429 \\
\hline $124-1,59$ & 1604.09 & & & 10.1 & 84 & 0.4 & 83 & 115 & 0.32 & 433 \\
\hline $125-2,100$ & 1615.00 & & & 2.5 & 21 & 1.8 & 161 & 37 & 2.95 & 431 \\
\hline $126-6,76$ & 1623.76 & & \multirow{2}{*}{$7 \mathrm{c}$} & 2.5 & 20 & 3.1 & 221 & 38 & 6.84 & \multirow{2}{*}{430} \\
\hline $127-2,32$ & 1632.32 & & & 2.6 & 22 & 0.4 & 58 & 105 & 0.27 & \\
\hline
\end{tabular}

tion. According to those studies, the "E1 Event" would have occurred in Hole 391C between Cores 10 and 11, or at the bottom of Core 10 , Core 11 being included with the Blake-Bahama Formation. Thus at Hole 391C, five subunits subdivide the Blake-Bahama Formation (Units 4 and 3, Cores 11-44).

Subunits $4 d$ and $4 c$ (Cores 391C-44 to 34), dated late Tithonian to early Valanginian, are composed of limestone and greenish gray shale layers, and are equivalent to Subunit 5d at Hole 534A (Fig. 4). The carbonate content is high $\left(42-86 \% \mathrm{CaCO}_{3}\right)$, and the organic carbon low $(0.2-0.6 \%)$. The origin of the organic matter is undetermined, with a low H.I. $(\leq 70)$ and a high O.I. (100-600) (Table 2, Fig. 3).

Subunit $4 b$ (Cores 391C-33 to 24), Valanginian to Hauterivian, is composed of massive or laminated limestones with black shale, and is equivalent to Subunit $5 \mathrm{c}$ at Hole 534A (Fig. 4). The carbonate contents fluctuate between 13 and $65 \% \mathrm{CaCO}_{3}$, and the organic carbon contents between 0.8 and $2.6 \%$ (Table 2). The organic matter has a detrital origin, except for the richer Sample $391 \mathrm{C}-28-2,89 \mathrm{~cm}$, where aquatic material is predominant (Table 2, Fig. 3).
Subunit $4 a$ (Cores 391C-23 to 14), dated late Valanginian to early Barremian, is composed of gray to olive gray limestones or shales with black silty laminated shales, and is equivalent to Subunit $5 \mathrm{~b}$ at Hole 534A (Fig. 4). The carbonate contents fluctuate between 24 and $90 \% \mathrm{CaCO}_{3}$, and the organic carbon contents between 0.2 and $0.8 \%$, except for three samples (391C$16-1,7 \mathrm{~cm}$; 391C-15-1, $114 \mathrm{~cm}$; and 391C-14-3, $54 \mathrm{~cm}$ ), which reach $1.6,1.1$, and $2.0 \%$, respectively (Table 2 ). In the richer samples the organic material is mainly detrital, whereas in the poorer samples it is residual.

Subunit 3c (Cores 391C-13 to 11), dated Barremian to early Aptian, is composed of dark marls that are variably calcareous and are equivalent to Subunit 5a of Hole 534A (Fig. 4). The less calcareous sediments contain 8 to $10 \% \mathrm{CaCO}_{3}$, whereas the richer ones have up to $74 \%$. The organic carbon contents are generally high: 0.5 to $4.2 \%$; the origin of the organic matter is mainly detrital, with a contribution of aquatic material in the organic-rich samples, as, for example, Sample 391C-11$2,22 \mathrm{~cm}$ (Table 2, Fig. 3).

We summarize in Table 3 the geochemical properties of the Blake-Bahama Formation at Holes 391C and 

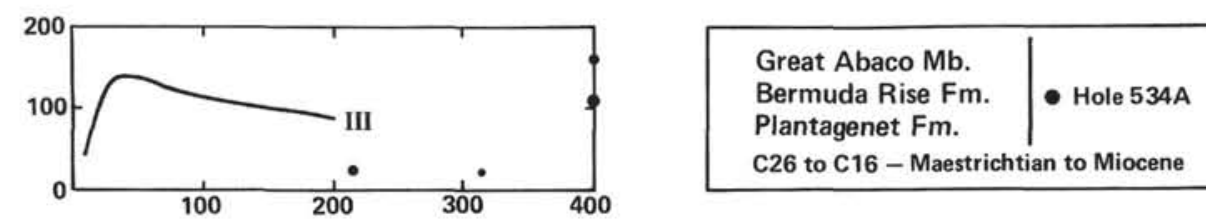

Great Abaco Mb.

Bermuda Rise Fm. • Hole 534A

Plantagenet $\mathrm{Fm}$.

C26 to C16 - Maestrichtian to Miocene
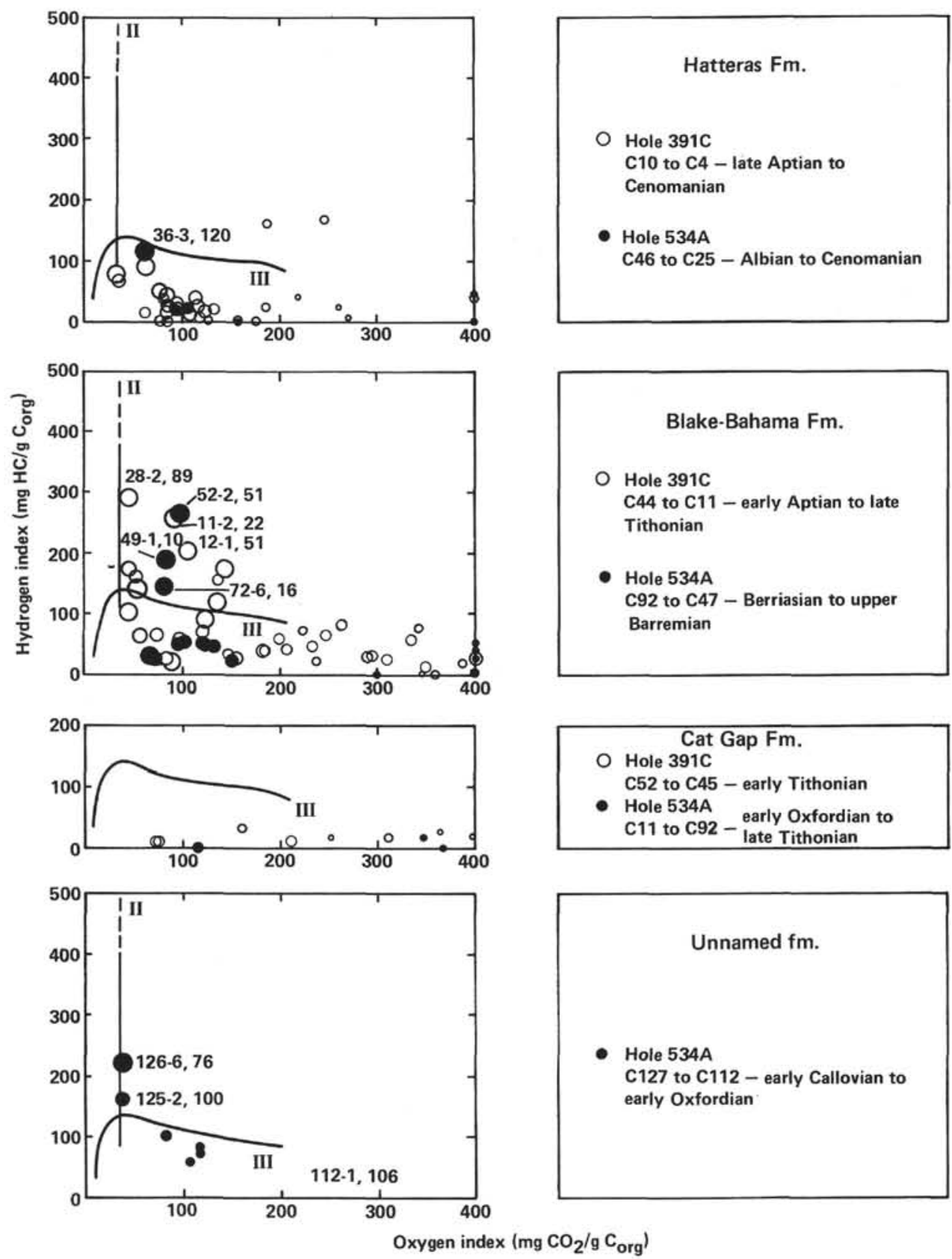

Figure 3. Diagrams of pyrolyses of the different formations for Holes $391 \mathrm{C}$ and 534A (the radii of the circles are proportional to the total organic carbon content $).(C 26=$ Core 26.$)$

534A. Some divergencies occur when ages of related subunits are compared. Nevertheless, the Blake-Bahama Formation at both sites is characterized at the bottom by lean contents of undetermined organic matter (o.m.) and at the top by concentrations of organic carbon $(2-4 \%)$ of a dominantly detrital origin, with some contribution of aquatic organic matter for the more organic-rich samples.

\section{Hatteras Formation}

Because this Formation was deposited in Hole 534A below the CCD, it contains very little carbonate. Three 


\section{J. P. HERBIN, G. DEROO, J. ROUCACHÉ}

Table 2. Carbonate, organic carbon, and pyrolysis data for Hole 391C samples.

\begin{tabular}{|c|c|c|c|c|c|}
\hline $\begin{array}{l}\text { Sample } \\
\text { (core-section, } \\
\text { interval } \\
\text { in } \mathrm{cm} \text { ) }\end{array}$ & $\begin{array}{l}\text { Depth } \\
\text { below } \\
\text { seafloor } \\
\text { (m) }\end{array}$ & $\begin{array}{c}\text { Geologica } \\
\text { formation } \\
\text { (Fm.) and } \\
\text { lithologica } \\
\text { units }\end{array}$ & & $\begin{array}{l}\text { Mineral } \\
\text { carbon } \\
\text { (wt. \%) }\end{array}$ & $\begin{array}{c}\mathrm{CaCO}_{3} \\
\text { equivalent } \\
\text { (wt.\%) }\end{array}$ \\
\hline $4-1,98$ & 668.98 & & & 0.0 & 0 \\
\hline $4-1,127$ & 669.27 & & & 0.5 & 4 \\
\hline $5-1,62$ & 678.12 & & & 0.0 & 0 \\
\hline $6-2,21$ & 688.71 & & & 0.4 & 3 \\
\hline $6-2,51$ & 689.01 & & & 0.2 & 2 \\
\hline $6 \cdot 2,75$ & 689.25 & & & 0.4 & 3 \\
\hline $6-2,102$ & 689.52 & & & 0.8 & 6 \\
\hline $6-2,139$ & 689.89 & & & 0.8 & 6 \\
\hline $6-3,102$ & 691.02 & & & 0.3 & 3 \\
\hline $6-3,145$ & 691.45 & & & 1.0 & 8 \\
\hline $6-4,12$ & 691.62 & & & 0.7 & 6 \\
\hline $6-4,118$ & 692.68 & & & 0.7 & 6 \\
\hline $6-5,82$ & 693.82 & & & 0.0 & 0 \\
\hline $6-6,84$ & 695.34 & & & 0.7 & 6 \\
\hline $6-6,144$ & 695.94 & & & 1.1 & 9 \\
\hline $7-2,18$ & 726.68 & & & 1.2 & 10 \\
\hline $7 \cdot 2,86$ & 727.36 & & & 1.1 & 9 \\
\hline $7.2,101$ & 727.51 & Hatteras & & 0.0 & 0 \\
\hline $7-2,135$ & 727,86 & $\mathrm{Fm}$. & & 0.3 & 3 \\
\hline $8-1,95$ & 782.96 & & & 1.2 & 10 \\
\hline $8 \cdot 2,33$ & 783.83 & & & 0.7 & 6 \\
\hline $8-2,59$ & 784.09 & & $3 \mathrm{~b}$ & 0.0 & 0 \\
\hline $8-2,145$ & 784.95 & & & 0.3 & 3 \\
\hline $9-1,71$ & 830.21 & & & 0.0 & 0 \\
\hline $9-1,88$ & 830.38 & & & 0.6 & 5 \\
\hline $9-2,10$ & 831.10 & & & 6.7 & 56 \\
\hline $9-2,56$ & 831.56 & & & 0.6 & 5 \\
\hline $9-2,86$ & 831.86 & & & 0.8 & 6 \\
\hline $9-2,108$ & 832.08 & & & 0.6 & 5 \\
\hline $9-2,126$ & 832.26 & & & 0.8 & 6 \\
\hline $9-3,145$ & 833.95 & & & 0.8 & 7 \\
\hline $10-1,101$ & 897.61 & & & 0.9 & 8 \\
\hline $10-1,131$ & 897.81 & & & 2.0 & 17 \\
\hline $10-2,67$ & 898.67 & & & 9.6 & 80 \\
\hline $10-3,42$ & 899.92 & & & 0.8 & 7 \\
\hline $10-3,127$ & 900.27 & & & 0.3 & 3 \\
\hline $10-3,145$ & 900.45 & & & 3.9 & 32 \\
\hline $11-1,10$ & 924.60 & & & 3.1 & 26 \\
\hline $11-1,97$ & 925.47 & & & 3.2 & 27 \\
\hline $11-1,108$ & 925.58 & & & 8.9 & 74 \\
\hline $11-1,149$ & 925.99 & & & 0.9 & 8 \\
\hline $11-2,22$ & 926.22 & Blake- & & 5.8 & 48 \\
\hline $11-2,80$ & 926.80 & Baha- " & '3c" & 3.3 & 27 \\
\hline $11-2,101$ & 927.01 & $\mathrm{ma}$ & & 5.4 & 45 \\
\hline $11-2,145$ & 927.45 & & & 8.2 & 69 \\
\hline $11-3,39$ & 927.89 & & & 3.7 & 31 \\
\hline $12-1,46$ & 953.46 & & & 3.7 & 31 \\
\hline $12-1,51$ & 953.51 & & & 3.9 & 33 \\
\hline $12-2,48$ & 954.98 & & & 7.0 & 58 \\
\hline $12-4,120$ & 958.70 & & & 1.2 & 10 \\
\hline $14-1,127$ & 1001.77 & & & 3.6 & 30 \\
\hline $14-2,137$ & 1003.37 & & & 10.8 & 90 \\
\hline $14-3,54$ & 1004.04 & & & 5.2 & 43 \\
\hline $15-1,114$ & 1011.14 & & & 2.9 & 24 \\
\hline $15-1,145$ & 1011.45 & & & 6.5 & 54 \\
\hline $15-3,89$ & 1013.69 & & & 5.3 & 44 \\
\hline $16-1,7$ & 1019.57 & & & 2.6 & 22 \\
\hline $16-2,87$ & 1021.87 & & $4 a$ & 8.3 & 69 \\
\hline $16-3,84$ & 1023.34 & & & 4.1 & 34 \\
\hline $16-4,16$ & 1024.16 & & & 10.2 & 85 \\
\hline $16-4,115$ & 1025.15 & & & 3.2 & 27 \\
\hline $17-2,32$ & 1030.82 & & & 2.8 & 23 \\
\hline $18-1,132$ & 1039.82 & & & 3.9 & 33 \\
\hline $20-1,124$ & 1058.74 & & & 6.1 & 51 \\
\hline $21-4,114$ & 1091.64 & & & 4.5 & 38 \\
\hline $24-6,46$ & 1131.96 & & & 4.5 & 38 \\
\hline $25-2,107$ & 1136.07 & $\begin{array}{l}\text { Blake- } \\
\text { Bahama }\end{array}$ & & 2.5 & 21 \\
\hline $26-3,72$ & 1146.72 & & & 4.6 & 39 \\
\hline $27-4,58$ & 1157.58 & $\mathrm{Fm}$. & & 4.2 & 35 \\
\hline $28-2,89$ & 1164.39 & & $4 \mathrm{~b}$ & 7.0 & 58 \\
\hline $30-3,55$ & 1184.55 & & & 1.6 & 13 \\
\hline $31-3,80$ & 1194.30 & & & 3.0 & 25 \\
\hline $32-3,101$ & 1204.01 & & & 7.4 & 62 \\
\hline $33-2,39$ & 1211.39 & & & 7.8 & 65 \\
\hline $34-3,69$ & 1222.59 & & & 8.5 & 71 \\
\hline $35-3,82$ & 1232.32 & & $4 c$ & 9.8 & 81 \\
\hline $36-3,136$ & 1242.36 & & & 7.0 & 58 \\
\hline $38-3,40$ & 1260.40 & & & 5.9 & 49 \\
\hline $39-2,17$ & 1268.17 & & & 5.6 & 47 \\
\hline $40-3,35$ & 1279.35 & & & 6.4 & 53 \\
\hline $41-2,102$ & 1288.02 & & $4 \mathrm{~d}$ & 6.2 & 51 \\
\hline $42-4,126$ & 1300.76 & & & 5.0 & 42 \\
\hline $43-3,25$ & 1307.75 & & & 10.3 & 86 \\
\hline $44-5,27$ & 1314.87 & & & 5.9 & 49 \\
\hline $45-2,99$ & 1325.99 & & & 5.2 & 43 \\
\hline $46-1,32$ & 1333.32 & & & 5.5 & 46 \\
\hline $47-1,94$ & 1343.44 & & $5 a$ & 4.0 & 33 \\
\hline $48-2,89$ & 1354.39 & & & 2.5 & 21 \\
\hline $49 \cdot 2,45$ & 1363.45 & $\begin{array}{l}\text { Gap } \\
\text { Fm. }\end{array}$ & & 1.4 & 12 \\
\hline $50-1,143$ & 1372.43 & & & 3.5 & 29 \\
\hline $51-2,89$ & 1382.39 & & $5 b$ & 2.6 & 22 \\
\hline $52-3,51$ & 1393.51 & & & 5.7 & 47 \\
\hline
\end{tabular}




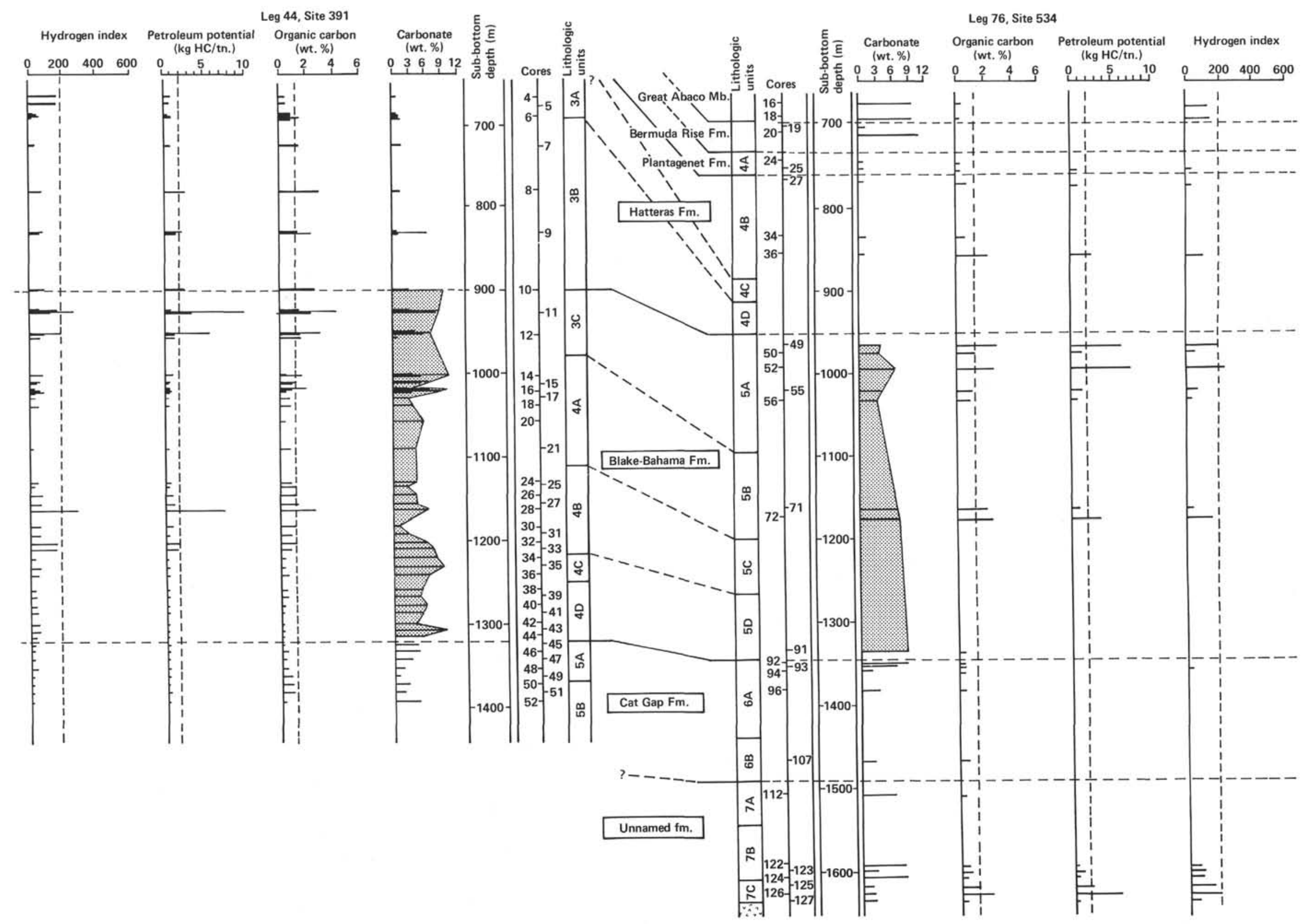


Table 3. Summary of geochemical properties of the Blake-Bahama Formation.

\begin{tabular}{|c|c|}
\hline Hole 534A & Hole $391 \mathrm{C}$. \\
\hline Subunit 5a: Cores $47-64$ & Subunit 3c: Cores $11-13$ \\
\hline $\begin{array}{l}\text { Barremian to Hauterivian, } 1.2 \leq \\
\text { TOC } \leq 3.1 \% \text {, mainly detrital } \\
\text { with contribution of aquatic o.m. } \\
\text { (Sample } 534 \mathrm{~A}-52-2,51 \mathrm{~cm} \text { ) }\end{array}$ & $\begin{array}{l}\text { Early Aptian to Barremian, } 0.5 \leq \\
\text { TOC } \leq 4.2 \% \text {, mainly detrital } \\
\text { with contribution of aquatic o.m. } \\
\text { (Sample } 391 \mathrm{C}-11-2,22 \mathrm{~cm} \text { ) }\end{array}$ \\
\hline Subunit 5b: Cores $65-75$ & Subunit 4a: Cores $14-23$ \\
\hline $\begin{array}{l}\text { Late Valanginian, } 1.5 \leq \mathrm{TOC} \leq \\
2.8 \% \text {, mainly detrital } 0 . \mathrm{m} \text {. with } \\
\text { contribution of aquatic } 0 . \mathrm{m} \text {. } \\
\text { (Sample } 534 \mathrm{~A}-72-6,16 \mathrm{~cm} \text { ) }\end{array}$ & $\begin{array}{l}\text { Early Barremian to late Valanginian, } \\
0.2 \leq \mathrm{TOC} \leq 2 \% \text {, mainly detrital } \\
\text { o.m. }\end{array}$ \\
\hline Subunit $5 \mathrm{c}$ : Cores $76-83$ & Subunit $4 \mathrm{~b}$ : Cores $24-33$ \\
\hline $\begin{array}{l}\text { Berriasian to Valanginian (no } \\
\text { samples) }\end{array}$ & $\begin{array}{l}\text { Hauterivian to Valanginian, } \\
0.8 \leq \text { TOC } \leq 2.6 \% \text {, mainly detri- } \\
\text { tal o.m. with contribution of } \\
\text { aquatic o.m. (Sample } 391 \mathrm{C}-28-2 \text {, } \\
89 \mathrm{~cm} \text { ) }\end{array}$ \\
\hline Subunit 5d: Cores $84-92$ & Subunits $4 c-4 d$ : Cores $34-44$ \\
\hline $\begin{array}{l}\text { Berriasian, } 0.2 \leq \mathrm{TOC} \leq 0.3 \% \text {, } \\
\text { undetermined o.m. }\end{array}$ & $\begin{array}{l}\text { Early Valanginian to late Tithonian, } \\
0.2 \leq \mathrm{TOC} \leq 0.6 \% \text {, undeter- } \\
\text { mined } 0 . \mathrm{m} \text {. }\end{array}$ \\
\hline
\end{tabular}

Note: $0 . m .=$ organic matter; TOC $=$ total organic carbon.

of the subunits of Unit 4 belong to it: $4 b, 4 c$, and $4 d$; Subunit $4 \mathrm{a}$ belongs to the Plantagenet Formation (Fig. 2).

Subunit $4 d$ (Cores 534A-46 to 43 ) is dated late Barremian to early Aptian, and Subunit 4c (Cores 534A-42 to 40 ) is dated late Aptian-early Albian(?). Subunit 4d consists of dark greenish gray and olive gray calcareous, silty claystone in the lower part, and greenish black to olive black carbonaceous claystone in the upper part. Subunit $4 \mathrm{c}$ is characterized by variegated claystones of a yellowish red, moderately brown, or greenish gray color. These units were not sampled.

Subunit $4 b$ (Cores 534A-39 to 27) is dated Albian to Cenomanian(?). In the lower part (Cores 39-31) this subunit is composed mainly of black, dark gray, or greenish black carbonaceous claystone 2 to $60 \mathrm{~cm}$ thick, and interbedded with dark greenish gray and greenish black silty claystones 1 to $50 \mathrm{~cm}$ thick. Abundances of quartz, smectite, and kaolinite in the clay minerals suggest the input of terrigenous materials (Site 534 report, this volume). In the upper part (from Cores 30-27), the subunit is composed of dominantly silty claystones, except Core 29 , where the carbonaceous peak is recognized that can be correlated with the so-called Cenomanian abundance spike (Site 534 report, this volume). In the silty, claystone-rich interval, the carbonaceous claystones range from 2 to $30 \mathrm{~cm}$ in thickness, whereas silty claystones are 5 to $50 \mathrm{~cm}$ in thickness (Site 534 report, this volume).

The carbonate contents are low $\left(9-11 \% \mathrm{CaCO}_{3}\right)$, and the organic carbon contents are not very high, around $0.9 \%$ in two samples of black claystone, reaching $2.6 \%$ in Sample 534A-36-3, $120 \mathrm{~cm}$ (Table 1). The organic matter is mainly of detrital origin, with a low H.I. (Fig. 3 ), and some contribution of marine material in this sample.

The maximum of the organic matter concentration observed at the top of the Hatteras Formation (Jansa et al., 1979) and correlative to the "E2 Event" (C. Müller et al., personal communication, 1982; de Graciansky et al., 1982; Herbin and Deroo, in press) was not recognized here; our sampling was not sufficient. Furthermore, this phenomenon occurs only within a thickness of a few centimeters (at Sites 105, 398), and if recovery is poor the event can be missed!

At Hole 391C, the Hatteras Formation extends from Core 3 to Core 10. From bottom to top two subunits were distinguished.

Subunit $3 b$ (Cores 391C-10 to 7), dated from the middle part of the late Aptian to the middle and late Albian, is composed of dark greenish gray, olive gray, and black claystones. These claystones are very low in carbonate content: 0 to $17 \% \mathrm{CaCO}_{3}$, except the redeposited carbonate, which can reach up to $80 \%$ (Table 2 ). In the black claystones the organic carbon contents fluctuate between 0.4 and $3.0 \%$ and consist of detrital organic matter; in the dark greenish gray and olive gray claystones the organic carbon contents do not exceed $0.5 \%$ and consist of undetermined organic matter (Table 2, Fig. 3).

Subunit $3 a$ (Cores 391C-6 to 3) is dated from the late Albian, through the Vraconian, to the early Cenomanian. The variegated claystones $\left(0-6 \% \mathrm{CaCO}_{3}\right)$ are poor in organic carbon $(0.2-0.9 \%)$, and the organic matter is either detrital or undetermined. According to the lithology, Subunit 3a would correspond to Subunit $4 \mathrm{c}$ of Hole 534A.

A comparison of the Hatteras Formation in Holes $391 \mathrm{C}$ and 534A is not easy because the equivalent of Subunit $4 \mathrm{~b}$ of Hole 534A was eroded at Hole $391 \mathrm{C}$ and Subunits $3 \mathrm{a}$ and $3 \mathrm{~b}$ of the latter hole, which correspond to Subunits $4 \mathrm{c}$ and $4 \mathrm{~d}$ of Hole $534 \mathrm{~A}$, were unsampled! On the other hand, the combination of the two holes could give a representative sampling of the Hatteras Formation, except for the top of the formation (the "E2 Event"), for which the concentration and type of organic matter were not recognized. Nevertheless we do know, from other sites of the American margin (Site 105), some features of the "E2 Event," such as strong condensation of deposits due to very low rates of accumulation during the middle Cenomanian and Turonian. We can imagine that the same phenomenon exists at Site 534 , but the recovery was too poor to allow a detailed study.

\section{Plantagenet Formation}

In Hole 534A, the Plantagenet Formation consists mainly of variegated claystones of reddish brown, dark yellowish orange, greenish gray, and medium bluish gray colors. This Formation extends from Cores 26 to 24 (Subunit 4a, Fig. 2). Dating is not very accurate (as usual in this Formation), but the unit is probably Maestrichtian. Carbonate contents are low (around 5-7\% $\mathrm{CaCO}_{3}$ (Table 1); the low organic carbon contents $(0.1-$ $0.3 \%$ ) are related to undetermined organic matter that has undergone extensive alteration and/or oxidation (Table 1, Fig. 3).

At Hole 391C no Plantagenet material was examined; it appears to be missing (Sheridan et al., 1978). 


\section{Bermuda Rise Formation}

This late Eocene Formation consists almost entirely of greenish, yellowish gray, or very pale orange claystones. A lot of sedimentary structures appear in the typical greenish claystones (parallel lamination, burrows, etc.), some of them belonging to Bouma sequences. Two samples were studied from Hole 534A (Table 1, Fig. 3). In Core 20 a silty micritic chalk contains $96 \%$ $\mathrm{CaCO}_{3}$, whereas in Core 19 , a yellowish gray claystone, $\mathrm{CaCO}_{3}$ does not exceed $11 \%$. In both samples the organic carbon content is very low $(0.1 \%)$; the organic matter, heavily altered or oxidized, is classified as undetermined.

\section{Great Abaco Member}

This Miocene deposit is composed mostly of intraclastic chalk, siliceous and calcareous claystone and mudstone, and minor limestone. Similar lithologies occur at Site 391 but were not studied there. Samples from Subunit 2d (Hole 534A), which is a relatively uniform sequence of greenish gray chalk, are rich in carbonate (77$84 \%$ ) and have low organic carbon contents $(0.3 \%)$ correlated to undetermined organic matter (Table 1, Fig. 3).

\section{PETROLEUM POTENTIAL AND MATURATION OF ORGANIC MATTER IN THE DIFFERENT FORMATIONS OF HOLES 391C AND 534A}

The petroleum potential is the sum of peak $S_{1}$ (i.e., the free hydrocarbons in the rock) and peak $S_{2}$ (i.e., the hydrocarbons resulting from pyrolysis of the kerogen) (Espitalié et al. 1977). Five ranges of petroleum potential are considered:

1) Very low potentials: between 0.01 and $0.50 \mathrm{~kg}$ $\mathrm{HC} / \mathrm{T}$ of rock

2) Low potentials: between 0.51 and $2.00 \mathrm{~kg} \mathrm{HC} / \mathrm{T}$ of rock

3) Medium potentials: between 2.01 and $5.00 \mathrm{~kg}$ $\mathrm{HC} / \mathrm{T}$ of rock

4) Good potentials: between 5.01 and $20.00 \mathrm{~kg}$ $\mathrm{HC} / \mathrm{T}$ of rock

5) Very good potentials: above $20 \mathrm{~kg} \mathrm{HC} / \mathrm{T}$ of rock

The maturation stage of source rocks can be defined by the temperature at which the $\mathrm{S}_{2}$ pyrolysis peak is maximum. This maximum temperature increases with the degree of evolution. Temperatures between 400 and $435^{\circ} \mathrm{C}$ correspond approximatively to the immature zone. The oil window or mature zone is characterized by temperatures between 435 and $460^{\circ} \mathrm{C}$. Above $460^{\circ} \mathrm{C}$ it is the gas zone or metamorphosed zone.

The vertical distribution of the petroleum potential, shown in Figure 4, and the maturity of organic matter, shown in Fig. 5, are described in the following sections.

\section{Unnamed Formation}

In the Callovian section the petroleum potential of organic-rich samples is medium to good. The olive black claystone (in Sample 534A-126-2, $76 \mathrm{~cm}$ ), which contains $3.1 \%$ organic carbon, has a petroleum potential of 6.8 $\mathrm{kg} \mathrm{HC} / \mathrm{T}$ of rock. The stage of maturation of these samples is not very high; they just reach the beginning of the oil window, with a temperature range of 429 to $433^{\circ} \mathrm{C}$
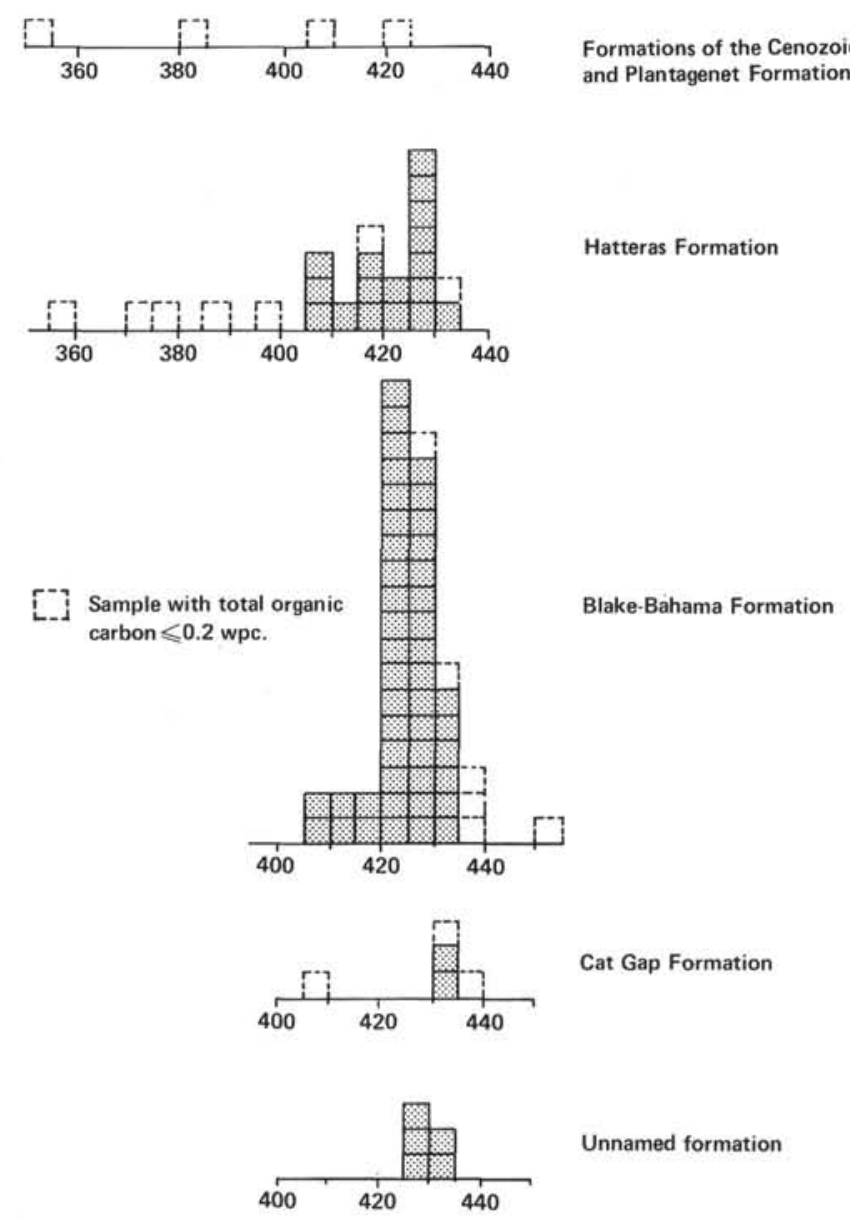

Figure 5. Maturation of the organic matter $\left(\mathrm{T} \max .{ }^{\circ} \mathrm{C}\right)$ in the different formations of Sites 391 and 534. (Samples with total organic carbon $\leq 0.2 \%$ are dotted.)

and an average of $430^{\circ} \mathrm{C}$ (Fig. 5), which is equivalent to a vitrinite reflectance value of about 0.5 (Espitalié et al., 1977).

\section{Cat Gap Formation}

From the Oxfordian to the Berriasian the section is devoid of petroleum potential. Thus the maturity of the organic matter cannot be defined.

\section{Blake-Bahama Formation}

During the Berriasian (Site 534) or early Valanginian (Site 391), at the bottom of the Blake-Bahama Formation, the petroleum potential is very low $(\leq 0.3 \mathrm{~kg} \mathrm{HC} / \mathrm{T}$ of rock). From the late Valanginian to the Barremian, the petroleum potential depends on the organic carbon content: When the organic carbon content is less than $2 \%$, and the organic matter mainly detrital, the petroleum potential is low ( $<2 \mathrm{~kg} \mathrm{HC} / \mathrm{T}$ of rock). In contrast, when the organic carbon content is more than $2 \%$, with a contribution of aquatic organic matter with the detrital material, the petroleum potential is medium to good (up to $11 \mathrm{~kg} \mathrm{HC} / \mathrm{T}$ of rock).

The maturity of these samples seems lower than it was in the unnamed formation, with a pyrolysis temperature maximum between 420 and $425^{\circ} \mathrm{C}$ (Fig. 5), al- 
Table 4. Composition of the extracts from Hole 534A samples.

\begin{tabular}{|c|c|c|c|c|c|c|c|}
\hline $\begin{array}{l}\text { Sample } \\
\text { (core-section, } \\
\text { interval } \\
\text { in } \mathrm{cm} \text { ) }\end{array}$ & $\begin{array}{l}\text { Sub- } \\
\text { bottom } \\
\text { depth } \\
\text { (m) }\end{array}$ & Formations & Subunits & Age & $\begin{array}{l}\text { Weight } \\
\text { of rock } \\
\text { analyzed } \\
(\mathrm{g})\end{array}$ & $\begin{array}{l}\text { Equivalent } \\
\mathrm{CaCO}_{3} \\
\text { (wt.\%) }\end{array}$ & $\begin{array}{l}\text { Total } \\
\text { organic } \\
\text { carbon } \\
(\mathrm{TOC}-\%)\end{array}$ \\
\hline $\begin{array}{l}27-2,82^{\mathrm{a}} \\
34-2,70^{\mathrm{a}} \\
36-3,120^{\mathrm{a}} \\
\end{array}$ & $\begin{array}{l}766.82 \\
833.20 \\
854.20 \\
\end{array}$ & $\begin{array}{l}\text { Hatteras } \\
\quad \text { Formation }\end{array}$ & $4 b$ & $\begin{array}{l}\text { Cenomanian } \\
\text { middle Albian } \\
\text { middle Albian }\end{array}$ & $\begin{array}{l}10.3 \\
11.1 \\
11.5\end{array}$ & $\begin{array}{r}9 \\
10 \\
11 \\
\end{array}$ & $\begin{array}{l}0.88 \\
0.85 \\
2.60\end{array}$ \\
\hline $\begin{array}{l}49-1,10 \\
50-1,59^{\mathrm{a}} \\
52-2,51 \\
55-2,57^{\mathrm{a}} \\
56-2,47 \\
\end{array}$ & $\begin{array}{r}963.60 \\
973.09 \\
992.51 \\
1019.57 \\
1030.47 \\
\end{array}$ & \multirow[t]{2}{*}{$\begin{array}{l}\text { Blake- } \\
\text { Bahama } \\
\text { Formation }\end{array}$} & $5 \mathrm{a}$ & $\begin{array}{l}\text { Barremian } \\
\text { Barremian } \\
\text { early Barremian } \\
\text { late Hauterivian } \\
\text { late Hauterivian }\end{array}$ & $\begin{array}{l}15.8 \\
14.0 \\
12.9 \\
23.0 \\
21.8 \\
\end{array}$ & $\begin{array}{l}35 \\
32 \\
57 \\
38 \\
30 \\
\end{array}$ & $\begin{array}{l}3.10 \\
1.52 \\
2.83 \\
1.36 \\
1.18 \\
\end{array}$ \\
\hline $\begin{array}{l}71-4,42 \\
72-6,16^{a} \\
72-6,16 \\
\end{array}$ & $\begin{array}{l}1161.92 \\
1173.66 \\
1173.66 \\
\end{array}$ & & $5 b$ & $\begin{array}{l}\text { Valanginian } \\
\text { Valanginian } \\
\text { Valanginian }\end{array}$ & $\begin{array}{r}18.6 \\
11.0 \\
1.9 \\
\end{array}$ & $\begin{array}{l}34 \\
17 \\
64 \\
\end{array}$ & $\begin{array}{l}1.46 \\
2.00 \\
2.76\end{array}$ \\
\hline $\begin{array}{l}122-1,35^{\mathrm{a}} \\
123-3,20^{\mathrm{a}} \\
125-2,100^{\mathrm{a}}\end{array}$ & $\begin{array}{l}1590.35 \\
1597.20 \\
1615.00\end{array}$ & \multirow{2}{*}{$\begin{array}{l}\text { Unnamed } \\
\text { formation }\end{array}$} & $7 b$ & $\begin{array}{l}\text { Callovian to Oxfordian } \\
\text { middle-late Callovian } \\
\text { middle Callovian }\end{array}$ & $\begin{array}{r}85.0 \\
39.0 \\
117.0 \\
\end{array}$ & $\begin{array}{l}70 \\
26 \\
21 \\
\end{array}$ & $\begin{array}{l}0.46 \\
0.86 \\
1.82 \\
\end{array}$ \\
\hline $126-2,76^{\mathrm{a}}$ & 1623.76 & & $7 \mathrm{c}$ & middle Callovian & 30.0 & 20 & 3.09 \\
\hline
\end{tabular}

Note: - indicates data not available.

a Study of the saturated and unsaturated fraction by gas chromatography analysis on quartz capillary column CP SIL 5 ( $\phi$ int: $0.5 \mathrm{~mm}, \mathrm{~L}=25 \mathrm{~m}$ ), injected $0.2 \mu \mathrm{l}$ splitless (Varian 3700 model).

${ }^{\mathrm{b}}$ Gram of extract versus $100 \mathrm{~g}$ of rock.

c Gram of extract versus $100 \mathrm{~g}$ of TOC (total organic carbon).

though numerous samples have temperatures between 425 and $435^{\circ} \mathrm{C}$.

\section{Hatteras Formation}

The characteristics observed in the Blake-Bahama Formation were observed again in the Hatteras Formation. Effectively, the lower organic carbon contents (less than $2 \%$ ) correspond to low petroleum potentials $(<1$ $\mathrm{kg} \mathrm{HC} / \mathrm{T}$ of rock). Only a few samples with organic carbons (2.4-3.0\%) show medium petroleum potentials (between 2 and $3 \mathrm{~kg} \mathrm{HC} / \mathrm{T}$ of rock).

The distributions of temperature maxima show great variation, ranging from 406 to $433^{\circ} \mathrm{C}$ (Fig. 5); because this formation is characterized by detrital organic matter, reworked material may contribute to the dispersion of data.

\section{Plantagenet Formation, Bermuda Rise Formation, and Great Abaco Member}

Above the Hatteras Formation, from the Upper Cretaceous to the Miocene, the section is wholly devoid of petroleum potential and the maturity may not be characterized, because of the low content of organic matter.

\section{STUDIES OF CHLOROFORM EXTRACTS}

Fifteen samples from Hole 534A were extracted with chloroform. Quantitative detection of saturated and unsaturated, aromatic hydrocarbon fractions and NSO fractions was made with an IATROSCAN TH.IO TLC/ FID Analyzer. These components were fractionated by thin-layer chromatography on thin silica gel-coated rods passing through a flame ionization detector in order to measure their abundance. Ten micrograms of total extract are required for this destructive method. Then ten of the samples underwent a new separation by thin-layer chromatography without solvent evaporation in order to examine by gas chromatography the saturated and unsaturated hydrocarbon fractions.

Analytical data are presented in Table 4. Because of the small sample sizes (10-20 g, on the average) the extract yields were very low-less than an average of $4 \mathrm{mg}$, ranging from $0.7 \mathrm{mg}$ (Sample 534A-72-6, $16 \mathrm{~cm}$ ) to 5.7 $\mathrm{mg}$ (Sample 534A-52-2, $51 \mathrm{~cm}$ ), except in Sample 534A$125-2,100 \mathrm{~cm}$, where we obtained $44 \mathrm{mg}$. NSO compounds form 79 to $99 \%$ of the extracts (Table 4). The low content of hydrocarbons, predominantly heteroatomic compounds, is typical of immature material.

The saturated and unsaturated hydrocarbons are either nondetectable or range from 2.0 to $12.5 \%$, and the aromatic fractions represent between 2.2 and $14.2 \%$ of the extracts. The saturated and unsaturated hydrocarbons are less abundant in Unit $7(2.0-4.9 \%)$ than in Units 4 and $5(4.6-12.5 \%)$, and the saturated and unsaturated $\mathrm{HC} /$ aromatic $\mathrm{HC}$ ratio is more often $<1$ in Unit 7 and $>1$ in Units 4 and 5.

\section{Units 4 and 5}

Two extracts illustrate the homogeneity of the material in these units: Samples 534A-36-3, $120 \mathrm{~cm}$ in Subunit $4 \mathrm{~b}$ of the Hatteras Formation and 534A-72-6, 16 $\mathrm{cm}$ in Subunit $5 \mathrm{~b}$ of the Blake-Bahama Formation. Their chromatograms are very similar (Fig. 6). The normal alkanes are especially well represented in the $n \mathrm{C}_{23}$ to $n \mathrm{C}_{31}$ and exhibit a predominance of odd over even carbon numbers. The fraction before $n \mathrm{C}_{23}$ is poorly represented.

These characteristics suggest an important contribution from higher plants. In Site 391, equivalent samples 
Table 4. (Continued).

\begin{tabular}{|c|c|c|c|c|c|c|c|c|}
\hline \multirow[b]{2}{*}{$\begin{array}{l}\text { Hydrogen } \\
\text { index } \\
\text { (H.I) }\end{array}$} & \multirow[b]{2}{*}{$\begin{array}{l}\text { Oxygen } \\
\text { index } \\
\text { (O.I.) }\end{array}$} & \multirow[b]{2}{*}{$\begin{array}{l}\mathrm{T}_{\max } \\
\left({ }^{\circ} \mathrm{C}\right)\end{array}$} & \multirow[b]{2}{*}{$\begin{array}{l}\text { Extract/ } \\
\text { rockb }\end{array}$} & \multirow[b]{2}{*}{$\begin{array}{l}\text { Extract/ } \\
\text { organic } \\
\text { carbonc }\end{array}$} & \multirow[b]{2}{*}{$\begin{array}{l}\text { NSO } \\
\text { compounds } \\
(\%)\end{array}$} & \multicolumn{3}{|c|}{ Hydrocarbon Fractions } \\
\hline & & & & & & $\begin{array}{c}\text { Aromatic } \\
(\%)\end{array}$ & $\begin{array}{c}\text { Saturated } \\
(\%)\end{array}$ & $\begin{array}{l}\text { Saturated } \\
\text { aromatic } \\
\text { ratio }\end{array}$ \\
\hline 20 & 106 & 376 & 0.008 & 0.91 & 81.7 & 11.8 & 6.5 & 0.56 \\
\hline 14 & 91 & 390 & 0.008 & 0.94 & 84.7 & 5.1 & 10.2 & 2.03 \\
\hline 114 & 62 & 428 & 0.023 & 0.88 & 91.7 & 3.7 & 4.6 & 1.84 \\
\hline 187 & 83 & 425 & 0.037 & 1.19 & 99.9 & 0 & 0.1 & - \\
\hline 47 & 120 & 412 & 0.013 & 0.85 & 81.8 & 5.7 & 12.5 & 2.18 \\
\hline 263 & 97 & 425 & 0.044 & 1.55 & 98.2 & 0 & 1.8 & - \\
\hline 44 & 139 & 421 & 0.014 & 1.03 & 79.4 & 14.2 & 6.4 & 0.45 \\
\hline 18 & 150 & 410 & 0.012 & 1.02 & 86.1 & 3.6 & 10.3 & 2.81 \\
\hline 49 & 95 & 425 & 0.014 & 0.96 & 86.5 & 3.7 & 9.8 & 2.70 \\
\hline 25 & 70 & 423 & 0.009 & 0.45 & 84.2 & 3.9 & 11.9 & 3.09 \\
\hline 145 & 82 & 429 & 0.040 & 1.45 & 92.2 & 2.2 & 4.6 & 2.11 \\
\hline 70 & 116 & 429 & 0.006 & 1.30 & 86.0 & 9.1 & 4.9 & 0.54 \\
\hline 102 & 81 & 429 & 0.012 & 1.39 & 88.5 & 7.6 & 3.9 & 0.52 \\
\hline 170 & 39 & 431 & 0.038 & 2.08 & 89.3 & 8.6 & 2.0 & 0.24 \\
\hline 221 & 38 & 430 & 0.040 & 1.29 & 89.6 & 7.9 & 2.5 & 0.31 \\
\hline
\end{tabular}

from the Hatteras Formation and the Blake-Bahama Formation show the same detrital organic matter deriving from continental higher plants (Deroo et al., 1978).

\section{Unit 7}

The saturated and unsaturated hydrocarbons in the unnamed formation are different from those of the Blake-Bahama and Hatteras formations (Fig. 6). They have two modes: one near $\mathrm{C}_{17}$ and one near $\mathrm{C}_{27}$, with an enrichment of light alkanes $\left(<\mathrm{C}_{23}\right)$ and a decrease of the odd over even carbon number predominance between $\mathrm{C}_{25}$ and $\mathrm{C}_{31}$. Furthermore, isoprenoids are significant, particularly pristane. In their study of Cretaceous sediments of the Atlantic Ocean, Roucaché et al. (1979) showed that this type of chromatogram pattern corresponded to a mixture of continental and aquatic organic matter, the latter being more abundant in Sample 534A125-2, $100 \mathrm{~cm}$ (Fig. 6).

Despite a poor representation of extracts compared to the total organic carbon (saturated plus unsaturated fractions that do not overstep $0.15 \%$ of the total organic carbon, whereas the pyrolyzable carbon reaches $20 \%$ of this carbon), both pyrolysis and extracts agree that aquatic organic material made an important contribution in the unnamed formation.

\section{CONCLUSION}

The comparison of Sites 534 and 391 on the continental margin of eastern North America allowed us to determine the distribution of the organic fraction in the different formations, from the Callovian to the Maestrichtian. The five Mesozoic formations can be characterized geochemically as follows:

In the Callovian to Oxfordian unnamed formation, which was cored for the first time in the North Atlantic Ocean, the sediments represent deposition in an anoxic environment and contain both aquatic and detrital mixed organic material. The petroleum potential is rather good, and the maturity is close to the beginning of the oil window for the sediments located at $1600 \mathrm{~m}$ sub-bottom depth. This type of sedimentation during the Middle Jurassic would imply a restricted marine circulation.

The Cat Gap Formation, dated from the Oxfordian to the late Tithonian (or Berriasian), is essentially devoid of organic matter: a drastic change occurred from the previous reducing environment to an oxidizing one. This Formation was drilled before at Site 105, and on the opposite side of the Mid-Atlantic Ridge, at Site 367. Thus it must be considered as typical of the Late Jurassic Atlantic.

The Blake-Bahama Formation, early Berriasian to Barremian-early Aptian, is characterized by rhythmic deposits in which detrital organic matter that may be mixed with aquatic material occurs in the finely parallel laminated claystones, whereas the more carbonate-rich sediments are depleted in organic matter. The petroleum potential is medium to good in the organic-rich layers. Anoxic conditions reappeared and prevailed during the Early Cretaceous, allowing aquatic organic matter to be preserved.

The Hatteras Formation is separated from the BlakeBahama Formation by the "E1 Event," which corresponds to the rise of the CCD. This formation is characterized by "black shale" facies. It is more or less carbonaceous, the organic matter being mainly detrital and in some places aquatic. Anoxic conditions must have prevailed from the Albian to the Cenomanian, with occasional oxidizing periods resulting in alternations with green clays and sometimes red clays (Site 391). In this formation the petroleum potential is good, especially in the organic-rich layers.

The "E2 Event" of the middle Cenomanian to the Turonian, which is characterized by a very low rate of sedimentation and concentrations of organic matter of aquatic origin at the top of the Hatteras Formation, does exist. Such deposits revealed a high petroleum po- 
Hatteras Formation

Sample 534A-36-3, $120 \mathrm{~cm}$

854.2 m sub-bottom

(Subunit 4b) middle Albian

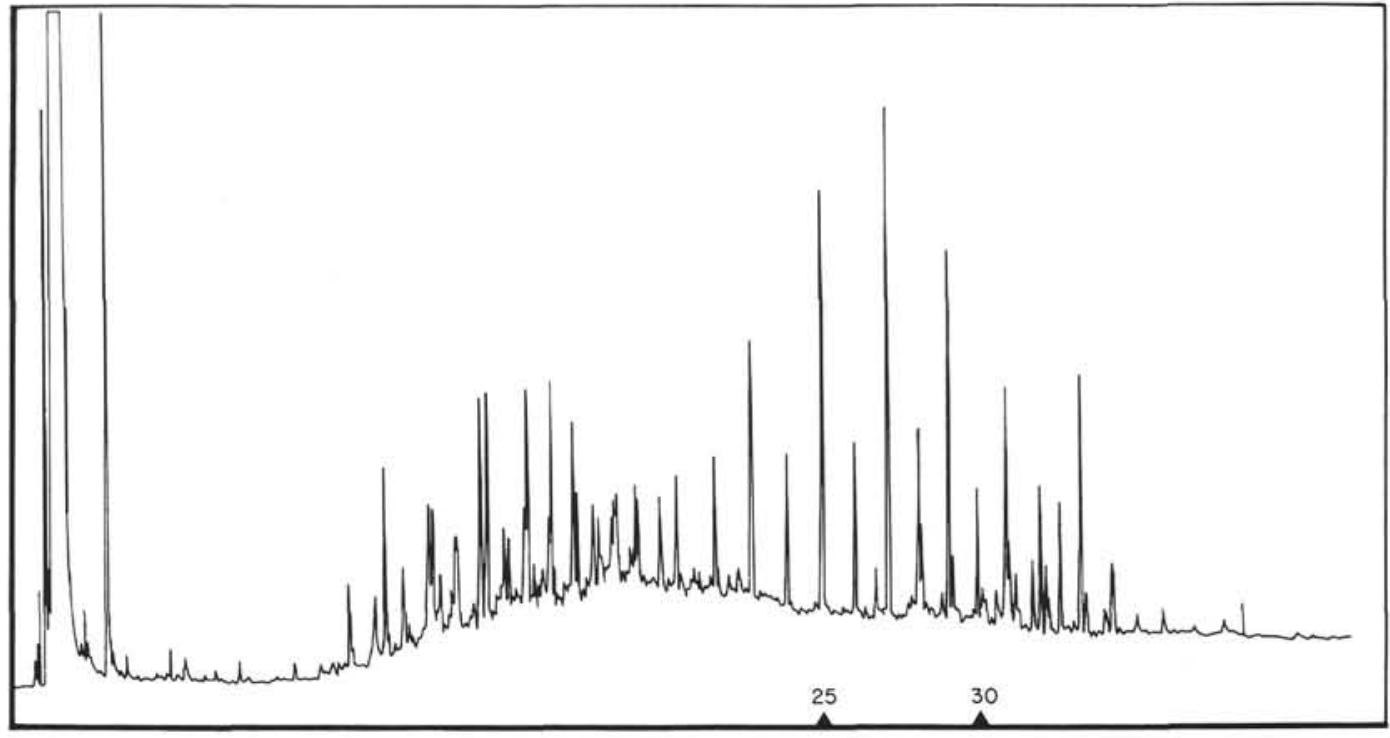

Blake-Bahama Formation

Sample 534A-72-6, $16 \mathrm{~cm}$

$1173.66 \mathrm{~m}$ sub-bottom

(Subunit 5b) early Valanginian
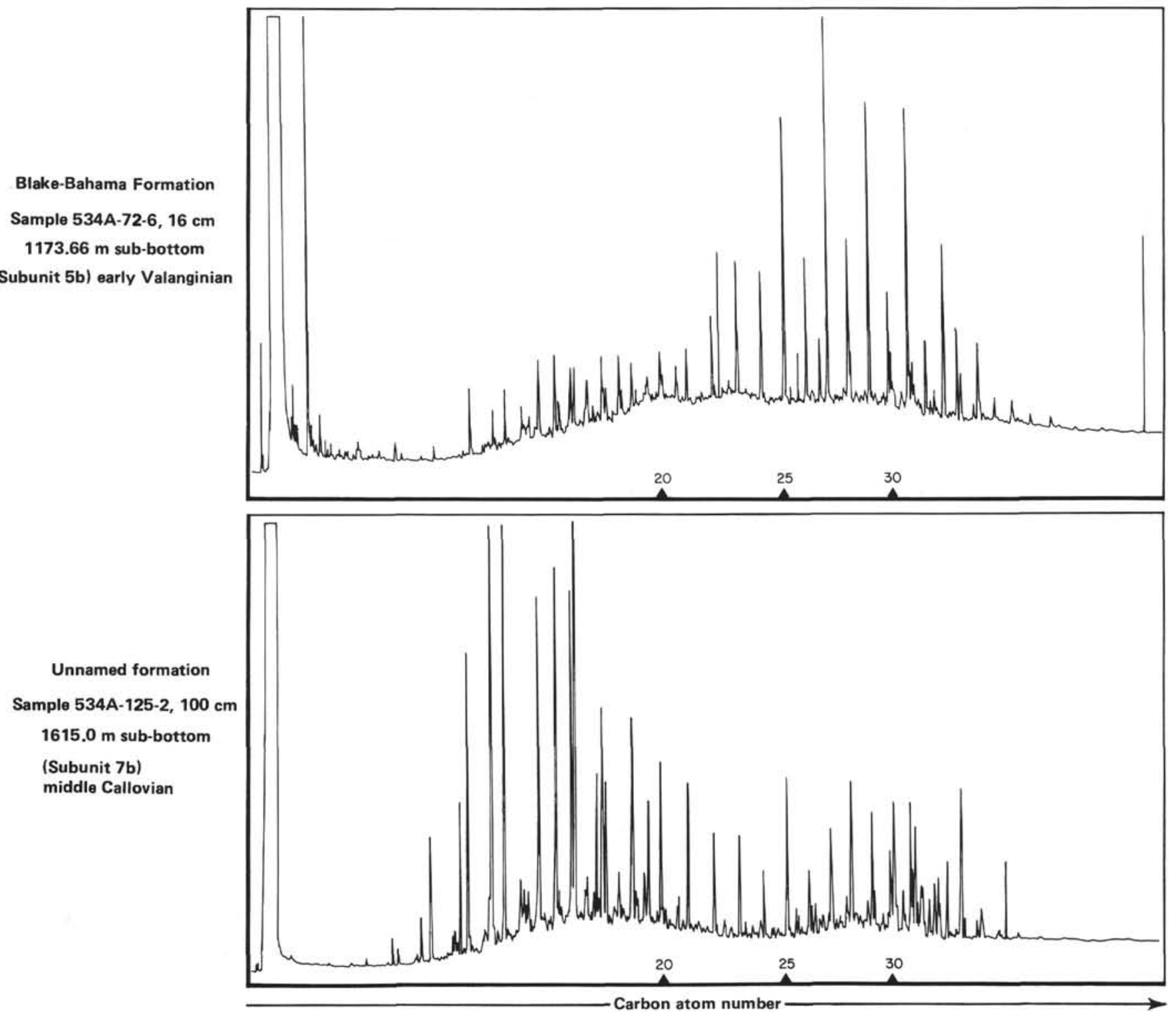

Figure 6. Chromatogram of the saturated and unsaturated hydrocarbon fractions in rock samples from Site 534. 
tential, reaching to $75 \mathrm{~kg} \mathrm{HC} / \mathrm{T}$ of rock at Site 105 . These deposits were not observed in Hole 534A, as the recovery for Cores 26 and 27 was poor.

The Plantagenet Formation does not exhibit a major change in the lithofacies compared to the Hatteras Formation, but does show a color change due to the variations in the conditions of oxidation and reduction; no "black shales" were found. The lithofacies are characteristic of the very oxidized environments that prevailed to the Cenozoic (Bermuda Rise Formation, Great Abaco Member). In these environments organic matter is completely destroyed, along with petroleum potential.

\section{ACKNOWLEDGMENTS}

The authors are indebted to Dr. B. R. T. Simoneit and Dr. C. Summerhayes for comments and review of this paper.

\section{REFERENCES}

de Graciansky, P. C., Brosse, E., Deroo, G., Herbin, J. P., Montadert, L., Müller, C., Schaaf, A., and Sigal, J., 1982. Les formations d'âge Crétacé de l'Atlantique Nord et leur matière organique, paleogéographie et milieux de dépôt. Rev. Inst. Fr. Pet., 37:275-336.

Deroo, G., Herbin, J. P., Roucaché, J., and Tissot, B., 1978. Organic geochemistry of some Cretaceous claystones from Site 391. In Benson, W. E., Sheridan, R. E., et al., Init. Repts. DSDP, 44: Washington (U.S. Govt. Printing Office), 593-598.

Espitalié, J., Laporte, J. L., Madec, M., Marquis, F., Leplat, P., Paulet, J., and Boutefeu, A., 1977. Méthode rapide de caractérisation des roches-mères, de leur potentiel pétrolier et de leur degré d'evolution. Rev. Inst. Fr. Pet., 32:23-42.
Espitalié, J., Madec, M., Tissot, B., Mennig, J. J., and Leplat, P., 1977. Source rock characterization method for petroleum exploration. Proc. 9th Annu. Offshore Technol. Conf., Houston, paper 2935.

Herbin, J. P., and Deroo, G., in press. Sédimentologie de la matière organique dans les formations du Mésozoique de l'Atlantique Nord. S.G.F. Bulletin spécialisé “'Océans-paléocéans," $7^{\mathrm{em}}$ serie, 24(3):497-510.

Jansa, L. F., Enos, P., Tucholke, B. E., Gradstein, F. M., and Sheridan, R. E., 1979. Mesozoic-Cenozoic sedimentary formations of the North American Basin. In Talwani, M., Hay, W., Ryan, W. B. F. (Eds.), Deep Drilling Results in the Atlantic Ocean: Continental Margins and Paleoenvironment. Am. Geophys. Union, Maurice Ewing Series 3:1-57.

Roucaché, J., Deroo, G., and Boulet, R., 1979. Caractérisation par différentes méthodes physico-chimiques de types de matière organique dans des sédiments du Crétacé d'Atlantique en mer profonde. Rev. Inst. Fr. Pet., 34:191-220.

Sheridan, R. E., Enos, P., Gradstein, F., and Benson, W. E., 1978. Mesozoic and Cenozoic sedimentary environments of the western north Atlantic. In Benson, W. E., Sheridan, R. E., et al., Init. Repts. DSDP, 44: Washington (U.S. Govt. Printing Office), 971-979.

Tissot, B., Deroo, G., and Herbin, J. P., 1979. Organic matter in Cretaceous sediments of the North Atlantic, contribution to sedimentology and paleogeography. In Talwani, M., Hay, W., and Ryan, W. B. F., (Eds.), Deep Drilling Results in the Atlantic Ocean: Continental Margins and Paleoenvironment. Am. Geophys. Union, Maurice Ewing Series 3:362-374.

Tissot, B., Durand, B., Espitalié, J., and Combaz, A., 1974. Influence of the nature and diagenesis of organic matter in formation of petroleum. Am. Assoc. Pet. Geol., 58(3):499-506.

Date of Initial Receipt: August 30, 1982 